\title{
Beyond the reach of the whip: Chinese Investment in Papua New Guinea
}

\author{
By Graeme Smith \\ China Studies Centre, University of Sydney Business School
}

The phrase bian chang mo ji 鞭长莫及 (beyond the reach of the whip) captures the opportunities and the challenges faced by Chinese entrepreneurs and companies operating in countries such as Papua New Guinea, well beyond the effective reach of the Chinese state. It is tempting to draw on the better-known phrase tian gao huangdi yuan 天高皇帝远 (the Emperor is as far away as the sky), but this implies that Chinese businesses are up to nefarious activities in the Pacific, which is not universally the case, despite several accounts that would have you believe otherwise (Henderson and Reilly 2003; Crocombe 2007; Kocsis 2012).

Many of the Chinese I've interviewed in Papua New Guinea, be they Sichuanese mine workers at the Kurumbukare mine site, Fuqing merchants running stores on remote Karkar Island, or site managers from Guangzhou supervising the University of Goroka dormitories project, all admit to the same mistake: we thought it was in Africa. Africa has a lot of Guineas, after all. This article will examine the three primary forms of Chinese investment in Papua New Guinea: retail, infrastructure and mining.

II

Many of the Chinese l've interviewed in Papua New Guinea all admit to the same mistake: we thought it [Papua New Guinea] was in Africa.

A few numbers are useful for placing Chinese Outbound Direct Investment (ODI) in Papua New Guinea into context.

Chinese ODI stock in the Pacific (USD, millions)

\begin{tabular}{|l|l|l|l|l|l|l|}
\hline Country & $\mathbf{2 0 0 5}$ & $\mathbf{2 0 0 6}$ & $\mathbf{2 0 0 7}$ & $\mathbf{2 0 0 8}$ & $\mathbf{2 0 0 9}$ & $\mathbf{2 0 1 0}$ \\
\hline PNG & 8.43 & 61.3 & 258.1 & 289.9 & 315.1 & 323.3 \\
\hline Australia & 587.4 & 794.3 & 1444 & 3355 & 5863 & 7867 \\
\hline New Zealand & 35.2 & 51.27 & 51.17 & 69.6 & 93.8 & 159 \\
\hline Fiji & 9.55 & 18.7 & 22.4 & 30.6 & 33.0 & 39.4 \\
\hline Vanuatu & 2.73 & 2.73 & 2.73 & 2.73 & 7.75 & 12.8 \\
\hline
\end{tabular}

Data: Chinese Ministry of Commerce (MOFCOM), 2011, p. 93.

Most striking is the volatility of Chinese ODI, particularly in resource-rich countries, such as Australia and Papua New Guinea. Single projects, such as Chinalco's acquisition of a stake in Rio Tinto in 2009, or the commencement of PNG's Ramu Nickel project in 2007, can cause a sharp spike in the measured level of ODI. Large, state-owned companies undertook both of these ventures, and thus their investments are captured accurately by the Ministry of Commerce data set, which is based on surveys completed by Chinese companies on a monthly basis. 
However, this is only part of the picture, as investment by Chinese migrants and ODI sourced from private, small-scale enterprises is not captured in the official figures of any of the Western Pacific economies. In Vanuatu, which has seen a dramatic rise in Chinese investment in the retail and wholesale sector over the past decade (Radio Australia 2012), no rise in Chinese ODI was recorded in official figures from 2005-2008. In Solomon Islands, where riots in 2006 led to the burning of Honiara's Chinatown, no net ODI in-flow was recorded for the entire period from 2004 to 2010, although this can partly be attributed to the government of Solomon Islands recognising Taiwan, rather than the People's Republic of China.

Making up for the lack of MOFCOM data, researchers at the PNG Investment Promotion Authority (the agency that all foreign-owned enterprises register with) suggest that investment in the PNG retail sector is more significant than in mining, accounting for around 40 per cent of Chinese ODI, and overshadowing the muchpublicised Ramu nickel project. How, then, is the wave of investment in the retail sector and beyond playing out in Papua New Guinea and how does it affect local communities?

Table 2 China-PNG Imports and Exports

\begin{tabular}{|l|l|l|}
\hline Rank & Exports & Imports \\
\hline 1 & Machinery and parts & Wood, wood products and charcoal \\
\hline 2 & Iron and steel products & Fuel, oil and bitumen \\
\hline 3 & $\begin{array}{l}\text { Electrical equipment, sound } \\
\text { equipment and accessories }\end{array}$ & Cereals and dairy products \\
\hline 4 & Plastics and plastic products & \\
\hline 5 & Rubber and rubber products & \\
\hline 6 & Textiles (new, sets and used) & \\
\hline 7 & Footwear & \\
\hline 8 & Iron and steel & \\
\hline 9 & Vehicles and spare parts (no trains) & \\
\hline 10 & Furniture, bedding, prefabricated & \\
\hline
\end{tabular}

Data: MOFCOM and Chinese Embassy in Papua New Guinea, 2011, p. 16

II

While the inflow of ODI for 2010 was reported as only $\$ 5.3$ million, the trade volume between the two countries reached $\$ 1.13$ billion, a rise of 27 per cent on the previous year.

Before exploring what this means for the nature of Chinese engagement in Papua New Guinea, a brief examination of recent trade data for China and Papua New Guinea follows. While the inflow of ODI for 2010 was reported as only $\$ 5.3$ million (MOFCOM 2011, p. 87; all figures in USD), the trade volume between the two countries reached $\$ 1.13$ billion, a rise of 27 per cent on the previous year. Trade was very much in favour of Papua New Guinea, with China purchasing $\$ 780$ million worth of imports, more than double the value of its exports to Papua New Guinea (MOFCOM and Chinese Embassy in Papua New Guinea 2011, p. 16). The table above shows the breakdown in trade categories. 
While trade and investment volumes can be unrelated, the large gap between the volume of trade and the amount of investment (less than two per cent of the value of Chinese goods sold in Papua New Guinea) could be used to support PNG nationalists' claims that Chinese involvement in the economy is simply extractive and exploitative. Papua New Guinea is the second largest supplier of logs to China after Russia, and beyond serving a handful of politicians connected to the logging industry, there seems to be little economic benefit to Papua New Guinea. Malaysian Chinese companies dominate the logging industry (Filer 2012), so investment associated with forestry does not appear as Chinese ODI.

Chinese traders are highly visible in the retail and wholesale sectors, with their ubiquitous red plastic buckets and cheap shoes. Many Chinese shopkeepers do simply rent or buy existing shops. However, it is also common for small Chinese investors to build new shops or small factories from scratch, along with the electricity and water infrastructure needed to support them in remote areas, and bringing goods to communities that often never had them before.

\section{II}

Chinese traders are highly visible in the retail and wholesale sectors, with their ubiquitous red plastic buckets and cheap shoes.

While the Chinese state is effectively absent from the lives of its expatriate retail investors in Papua New Guinea, these shopkeepers dominate the retail trade in major towns across the country, and were the target of nationwide riots in May 2009, just as they were in the Solomon Islands in 2006 (Smith 2012). They have become a focus of resentment for local inhabitants, who believe Chinese entrepreneurs are monopolising business and employment opportunities and preventing local participation in the retail sector. The Papua New Guinean state recently responded to these concerns by launching a A\$56 million campaign, called the Stret Pasin Stoa (Fair-Deal Store) scheme, to assist local entrepreneurs trying to compete in the retail and restaurant sectors (Callick 2012). Funded by the National Development Bank of Papua New Guinea (NDB), the aim of the scheme, which "provides 100 per cent funding for our citizens to take over or build new shops, bakeries and kai (food) bars" is "to replace all non-citizen trade store and kai bar operators by citizen owners and operators" (NDB 2012). The scheme will be coupled with the reintroduction of the colonial era Reserve Activity Legislation, which will "lawfully disallow foreigners from owning and engaging in retail shops and kai bar businesses" (NDB 2012b). For their part, both old and new Chinese arrivals agree that they provide a convenient scapegoat for a state that has failed to improve the lot of most of its citizens.

While smaller-scale Chinese investors are expanding beyond retail, the capital raised for their ventures is still privately sourced. Around 90 per cent of the "new Chinese" merchants hail from the same town in Fujian province, Fuqing, which is renowned as a source of entrepreneurial migrants, both legal and illegal (Liu-Farrer 2009). As has been noted in Africa (Dobler 2009), the Chinese state has only a limited influence on these entrepreneurs' lives, mostly through its embassy in Port Moresby. The embassy assists with setting up friendship associations and mutual aid groups, but it has little capacity or inclination to intervene to protect its citizens-a policy that Chinese expatriates, in turn, have come to resent. As one shopkeeper complained, "Even when someone gets killed, they're no use. They'll just send out a notice telling you to take extra care, and not to go out." The Guide to Investment in Papua New Guinea does 
indeed contain this exact formulation (MOFCOM and the Chinese Embassy in Papua New Guinea 2011, p. 7). The authors of the guide cannot be accused of lacking a sense of humour; "social upheaval" is listed as a "transmissible disease" in Papua New Guinea, alongside malaria and dengue fever. The upside of the Chinese state's whip not reaching the shores of Papua New Guinea is that all retail traders, when asked whether it was easier to do business in China or Papua New Guinea, responded that the Pacific was easier. Although there is risk to their persons and property, Chinese traders face less competition, have fewer officials to "take care of," and can make higher returns than they would back in Fuqing.

Similar scope for "institutional escapism" (Wang and Wang 2011) is evident on the part of Chinese infrastructure providers in the Pacific. Researchers from Australia's most influential think tank, the Lowy Institute, have critiqued Chinese infrastructure aid in the Pacific, calling on the Chinese government to address issues of transparency, project quality and the impacts of debt (Hanson and Fifita 2011). They rightly raise concerns about excessive future debt burdens on Pacific Island nations such as Tonga. Such concerns have led to Papua New Guinea placing an unofficial freeze on further Chinese "soft loans" and to the Cook Islands putting "on hold" a \$37 million loan (which would have represented $17 \%$ of that nation's GDP) (Brant 2012). In PNG, the freeze was lifted during the course of the 2012 election campaign, with incumbent Prime Minister Peter O'Neill announcing China Exim Bank would provide a soft loan of US\$3 billion to rebuild the rapidly-deteriorating Highlands Highway. The loan is an order of magnitude larger than the $\$ 375$ million soft loan facility announced in April 2006 for the entire Pacific region. According to the Minister for Works, Francis Awesa, the Chinese side were "more than happy to give" up to $\$ 10$ billion. (Radio Australia; 2012b)

\section{The largest Chinese investor in Papua New Guinea, China Metallurgical Corporation, (MCC), is averse to the courts, yet has rarely found itself out of them.}

Yet for Chinese infrastructure providers in Papua New Guinea, there is nothing remarkable about international "aid," which they treat as just another type of investment. For companies such as the Chinese Overseas Engineering Group (the Asian Development Bank's favoured contractor for road-building projects in Papua New Guinea) and China Harbour Engineering, which recently won a US\$285 million project to build Phase I of the Tide Terminal project in Lae (Talu 2012), Chinese government aid projects are only a small part of their overseas business strategy. Moreover, contracting companies such as these are influential enough to attract support from the Chinese state for projects developed in collaboration with local partners in Papua New Guinea. Consequently, what first appears to be state-run aid often turns out to be contractor-driven ODI. These types of infrastructure projects are increasingly dominant in Chinese investment in Papua New Guinea. The longer Chinese contractors are based in a given country, the more likely this "bottom up" model of developing infrastructure assistance projects is to emerge (Smith 2012b). Chinese infrastructure providers are generally welcomed both by local partners and multilateral funding agencies, praised for their understanding in the face of delays, their ability to deliver projects on time and on budget, and their aversion to resorting to the courts.

The largest Chinese investor in Papua New Guinea, China Metallurgical Corporation, (MCC), is also averse to the courts, yet has rarely found itself out of them. The Ramu nickel project, managed and majority-owned by MCC, has suffered nearly two years of 
court delays. MCC recently conducted the mine's first on-load test (ACN Newswire 2012), which produced nickel and cobalt hydroxides, although it is expected that final processing will be undertaken in China.

Local resistance to the project has centred on environmental and labour issues so far (Matbob 2012), with one Australian broadsheet accusing the mine of bringing "neocolonial slavery" to PNG (Callick 2007). I'm yet to discover chain gangs or Chinese overlords with whips at the mine site, but there is no denying that the wages and conditions offered by Ramu Nickel generally fall short of those offered by other foreign mining companies. The company argues that a low-cost approach is dictated by the marginal nature of the mining project, and the four-decade gap between the discovery of an ore body (it was initially considered as a chromium deposit) and its exploitation seems to bear that out. But another issue of penny pinching could yet catch out MCC. With the construction phase now complete, future disputes may revolve around royalty payments to landowners. Under the mining development contract, which was negotiated with the former Somare government, in addition to a ten-year tax holiday, MCC will pay a low rate of royalties on revenue from resource sales, at 1.25 per cent. This figure is in accordance with Papua New Guinea's original Mining Act, rather than the 2 per cent presently paid by other mining projects. So if the project fails to deliver substantial royalties, and back of the envelope calculation suggests that it will not, it could face a new source of local opposition.

Despite being run by a company whose director argues that "central government enterprises that secure mines overseas are in reality securing resources for China" (Yan 2010), this project is not directly controlled from Beijing. Due to the emergence of MCC from the former Chinese Ministry of Metallurgy, the corporation is divided into provincebased corporations. The mine site at Kurumbukare is staffed by contractors from Sichuan province, while the refinery site has a wider variety of contractors, ranging from Tangshan (in northern China) to Shanghai. These contracting companies are brought in for specific tasks, and are financially independent from MCC's head office. Rather than constituting a single work unit, each site has a distinctive work culture based on shared histories, cultural preferences and local dialects.

\section{II}

This level of fragmentation and complexity, which is often found in both mining and infrastructure projects, presents challenges for local communities.

This level of fragmentation and complexity, which is often found in both mining and infrastructure projects, presents challenges for local communities. Many of the disputes at the Basamuk refinery site and along the pipeline route were caused by contracting companies that have now returned to China, leaving the Ramu Nickel management company to clean up, with varying degrees of success. Due to their financial separation from the parent company, some of the contractors engaged during the construction phase of the project had little long-term interest in the Ramu Nickel mine. Rather, their focus was on completing their specific task as quickly, and as cheaply, as possible. Often this led to health and safety issues not being addressed until major incidents arose, such as the accident that led to a large-scale riot at the Basamuk refinery in May 2009, or land being cleared before proper assessments for compensation had been made. But such fragmentation also presents numerous opportunities for Papua New Guinea, as it means Chinese actors are often more willing to compromise and adapt than other, longerestablished companies. 
Given all of these factors, the implications of Chinese investment in Papua New Guinea are more complex than media reports of 'neo-colonial slavery' suggest. Some analysts have called on the Chinese government to do more to rein in the broader effects of this sudden increase in ODI, such as illegal immigration and the reluctance of Chinese infrastructure companies to employ local labour, and there is evidence that elements within the Chinese state share these aspirations. But as Chinese ODI becomes an increasingly organic phenomenon in Papua New Guinea and beyond, the leverage of the Chinese state is becoming ever more limited. On the positive side, being beyond the reach of the whip means that Chinese actors can be more flexible in their engagements with local actors. Distinctions between "state-owned" and "private", "formal" and "informal" are losing their meaning within China; they mean still less in Papua New Guinea.

\section{References}

ACN Newswire (2012) "MCC Announces Successful On-load Test of Ramu Nico Mine." Available online at http://en.acnnewswire.com/press-release/english/8973/mccannounces-successful-on-load-test-of-ramu-nico-mine\#.T3KfipOkJew.email. Last accessed 16 May 2012.

Brant, Philippa (2012) "Chinese Aid in the South Pacific: Linked to Resources?" Asian Studies Review. Forthcoming.

Callick, Rowan (2007) China's neo-colonial slavery in PNG. The Australian. Available online at http://www.theaustralian.com.au/business/chinas-neo-colonial-slavery-inpng/story-e6frg8zx-1111112977807. Last accessed 16 May 2012.

Callick, Rowan (2012) "PNG aims to replace Asian entrepreneurs," The Australian. Available online at http://www.theaustralian.com.au/business/news/png-targets-asianentrepreneurs/story-e6frg906-1226296383710. Last accessed 15 May 2012.

Crocombe, Ron G. (2007) Asia in the Pacific Islands: Replacing the West. Suva: University of the South Pacific.

Dobler, Gregor (2009) "Chinese shops and the formation of a Chinese expatriate community in Namibia," The China Quarterly 199: 707-727.

Filer, Colin (2012) "Asian investment in the rural industries of Papua New Guinea: What's new, and what's not?" Pacific Affairs. Forthcoming.

Hanson, Fergus and Mary Fifita (2011) "China in the Pacific: the new banker in town." Available online at http://www.lowyinstitute.org/publications/china-pacific-new-bankertown. Last accessed 16 May 2012.

Henderson, John, and Benjamin Reilly (2003) "Dragon in Paradise: China's Rising Star in Oceania," The National Interest 72: 94-104.

Kocsis, John F.M. (2012) "Papua New Guinea's Great Power Conflict," Harvard Political Review. Available online at http://hpronline.org/world/papua-new-guinea-proxyfor-the-great-powers. Last accessed 17 May 2012.

Liu-Farrer, Gracia (2009) "Debt, networks, and reciprocity: undocumented migration from Fujian to Japan," Japan Focus. Available online at http://www.japanfocus.org/Gracia-Liu_Farrer/3377. Last accessed 16 May 2012.

Matbob, Almanzo (2012) "Doiwa condemns abuse of labour officer," Post Courier. Available online at http://www.postcourier.com.pg/20120322/news21.htm. Last accessed 16 May 2012. 
MOFCOM (2011), 2010 Statistical Bulletin of China Outward FDI. Available online at http://hzs.mofcom.gov.cn/accessory/201109/1316069658609.pdf. Last accessed 15 May 2012.

MOFCOM and the Chinese Embassy in Papua New Guinea (2011), "Duiwai touzi hezuo guobie (diqu) zhinan: babuya xin jineiya [Investment guide to countries and regions: Papua New Guinea]." Available online at http://fec.mofcom.gov.cn/gbzn/upload/babuyaxinjiny.pdf. Last accessed 15 May 2012.

NDB (2012), "NDB re-introduces the Stret Pasin Stoa scheme." Available online at http://ndbpng.wordpress.com/2012/02/17/national-development-bank-re-introduces-thestret-pasin-stoa-scheme. Last accessed 16 May 2012.

NDB (2012b), "Over 4000 couples apply to join the proposed NDB Stret Pasin Stoa Scheme." Available online at http://ndbpng.wordpress.com/2012/03/16/over-4000couples-apply-to-join-the-proposed-ndb-stret-pasin-stoa-scheme. Last accessed 16 May 2012.

Radio Australia (2012), "Large influx of Chinese migrants triggers concern in Pacific." Available online at http://www.radioaustralia.net.au/international/radio/onairhighlights/large-influx-ofchinese-migrants-triggers-concern-in-pacific. Last accessed 15 May 2012.

Radio Australia (2012b), "China offers to rebuild PNG's Highlands Highway." Available online at http://www.radioaustralia.net.au/international/radio/program/pacific-beat/chinaoffers-to-rebuild-pngs-highlands-highway/960820. Last accessed 14 June 2012.

Smith, Graeme (2012), "Chinese reactions to anti-Asian riots in the Pacific," Journal of Pacific History, 47(1): 93-109.

Smith, Graeme (2012b), "Are Chinese soft loans always a bad thing?" Lowy Interpreter Blog. Available online at http://www.lowyinterpreter.org/post/2012/03/29/Are-Chinesesoft-loans-always-a-bad-thing.aspx. Last accessed 16 May 2012.

Talu, Patrick (2012), "Chinese firm wins K600 million Lae Port contract," Post Courier. Available online at http://www.postcourier.com.pg/20120308/news05.htm. Last accessed 16 May 2012.

Wang, Bijun, and Huiyao Wang (2011) "Chinese manufacturing firms' overseas direct investment: patterns, motivations and challenges." In Rising China: Global Challenges and Opportunities, edited by Jane Golley and Ligang Song. Canberra: ANU E Press.

Yan Jiangning (2010) "MCC Chief Defends Overseas Resource Strategy," Caixin. Available online at http://english.caing.com/2010-09-08/100178056.html. Last accessed 16 May 2012.

Graeme Smith is a postdoctoral research fellow at the China Studies Centre, University of Sydney Business School, and an Australian Development Research Award fellow at the Australian National University. 埇閶 